\title{
Entre frestas: considerações sobre o teor ficcional, o teor de verdade e o teor testemunhal
}

\author{
Between cracks: considerations about the fictional content, the truth content and the \\ testimonial content \\ Augusto Nascimento SARMENTO-PANTOJA* \\ Universidade Federal do Pará (UFPA)
}

\begin{abstract}
RESUMO: o presente estudo está pautado nos debates que envolvem problemas e conceitos inerentes ao testemunho, dentre os quais um aspecto mais próximo dos estudos literários e culturais: a forte presença do teor testemunhal, tal como pensado por Márcio Seligmann-Silva, baseado em Walter Benjamin, presente em obras artísticas, as quais se revestem das estratégias narrativas do testemunho para se construir. De outro modo, analisamos em narrativas de testemunho o que chamamos aqui de teor ficcional, como parte de um complexo narrativo, que se utiliza de estratégias ficcionais para a construção do testemunho.
\end{abstract}

PALAVRAS-CHAVE: Testemunho/Teor testemunhal. Ficção/Teor ficcional. Verdade/Teor de verdade.

\begin{abstract}
: the present study is guided by the debates that involve problems and concepts inherent to the testimony, among which is an aspect closer to the literary and cultural studies: the strong presence of the testimonial content, as thought by Márcio Seligmann-Silva, based on Walter Benjamin, present in artistic works, which take on the narrative strategies of the testimony to build. Otherwise, we analyze in narratives of testimony what we call here fictional content, as part of a narrative complex, which uses fictional strategies for the construction of testimony.
\end{abstract}

KEYWORDS: Testimony/Testimonial content. Fiction/Fictional content. Truth/Truth content.

\footnotetext{
* Professor de Adjunto de Literatura Vernácula da Universidade Federal do Pará, Campus Universitário de Abaetetuba. Faculdade de Ciência da Linguagem. E-mail: a.sarmentopantoja@gmail.com
} 
No Cancioneiro, Fernando Pessoa, ao modo intimista, destaca que há no "longínquo horizonte" a possibilidade, mesmo quando ilusória, de o eu-lírico reviver e existir. Esse instante de autoconhecimento diante das névoas e dos muros construídos no interior do ser humano pode ser compreendido como uma fresta, uma brecha, uma fissura, que nos apresenta outra possibilidade, ora menos aterradora, como no poema de Fernando Pessoa; ora mais aterradora, pois, ao inverso, a impressão é de que tudo está bem, mas no fundo estamos diante de maus presságios. Em geral, a fresta se constitui em esperança diante do horror, mas pode expressar também a possibilidade do horror diante da felicidade, pois nem sempre aquilo que vemos é a realidade. A análise que proponho neste ensaio perpassa por essa esfera da fresta, na medida em que me proponho a refletir sobre a realidade como uma possibilidade de real, na intersecção do olhar sobre o discurso, a narrativa e o testemunho.

Desse modo, tomo como assertiva inicial a ideia de que a construção de um texto utiliza diversas estratégias, principalmente quando se trata da literatura contemporânea, pois desde a guinada modernista, no século XX, a literatura tem transitado bastante por misturas, fusões e recriações, muitas delas, impensáveis quando analisamos a produção literária anterior ao modernismo. Neste percurso, encontramos uma forte presença da oralidade na produção literária, como forma de aproximar, na maioria das vezes, a voz subalternizada à forma erudita do texto literário. É possível dizer também com 
segurança que o texto literário a partir desse período foi profundamente alterado pelos códigos e formatos textuais considerados mais objetivos, factográficos ou documentais, como as cartas, os manuais, os periódicos, as notícias, e outras formas arquivísticas que cada vez mais ganharam espaço na escrita literária. Por fim, temos nos deparado com modelos narrativos que se fundem e se ressignificam, como textos literários que parecem roteiros de cinema ou jogos de videogame cujas narrativas se valem dos mesmos elementos estruturais das narrativas literárias.

Esses hibridismos e compartilhamentos nos mostram o quão eclético ficou o texto literário, quando se trata de ultrapassar as fronteiras da dicotomia ficção e realidade. Contemporaneamente, essa dicotomia parece resolvida na teoria literária e em outros campos artísticos. Vilém Flusser, por exemplo, pontua a queda dessa fronteira ao refletir em Da ficção, publicado em 1966, o contraste presente já em Newton (século XVII) ao afirmar que suas "hypotheses non fingo (minhas hipóteses não são inventadas)", mas podem ser refutadas. Do mesmo modo, Wittgenstein (século XX) pondera sobre a materialidade de tal contradição ao considerar que "as ciências nada descobrem: inventam". A reflexão de Flusser se ampara no argumento de que não podemos separar esses dois campos, pois se de um lado temos o discurso sobre a necessidade da realidade, sabemos que ela é produto de ficções, ou seja, criações constituídas de verdades e pontos de vista particulares, sejam eles oriundos das ciências naturais, exatas ou humanas. Por isso ele assevera que "a realidade é o ponto de coincidência de ficções diferentes".

João Adolfo Hansen (2006), em $O$ "imortal" e a verossimilhança, nos apresenta uma boa reflexão sobre o fim dessa dicotomia ao justificar:

Quando a narração se refere a algo que realmente existe e o relaciona com um evento que não ocorreu em parte alguma, tem-se a "ficção primeira". Por exemplo, com a referência à existência de uma pessoa conhecida, Machado de Assis, inventa-se a ficção de algo que nunca ocorreu, como uma viagem à Inglaterra, onde Joaquim Maria faz contatos com uma leitora de Otelo chamada Capitolina. Tem-se a "fiç̧ão segunda" quando a narração se refere somente à essência dos seres; com a referência à essência, é possível inventar uma ficção verdadeira, como vera fictio, e uma ficção falsa, como falsa fictio. Com o exemplo desta, imaginemos uma história absurda, onde um inseto infinito voa num espaço que, teoricamente, deverá estar todo ocupado por seu corpo; ou uma personagem que tem uma alma quadrada. Ou, ainda, um homem imortal. (HANSEN, 2006, 59)

Revista Moara, n. 56, Vol. 2 jan-jul 2021 ISSN: 0104-0944 
Diante disso, não é meu interesse problematizar a fronteira entre ficção e realidade, contudo, constato que as aproximações e hibridismos observados se fazem presente em outras relações, como é o caso do testemunho e suas confluências com a literatura. Ainda que exista uma categoria que nos desloca para esta zona de fronteira: o teor testemunhal, categoria que dá conta da condição em que a literatura se apropria da forma do testemunho, ao mimetizar estratégias próprias desse tipo de discurso. Entretanto, penso que ainda não há uma categoria que reflita sobre o inverso desse movimento, ou seja, quando o testemunho se apropria de estratégias ficcionais. Penso, ainda, ser fundamental trazer esse debate tanto para a seara dos estudos literários, quanto para os estudos sobre testemunho, especialmente, quando se faz necessário compreender como estão dispostos os regimes de realidade em ambos os discursos, justamente porque há narrativas que escorregam, ora pela vera fiction ora pela falsa fiction, a depender da natureza e das dimensões estéticas que a obra percorre, como as observadas por Hansen, ao analisar tais estatutos na escrita machadiano.

Nesse sentido, o interesse aqui é o de tomar como ponto de partida a literatura e o testemunho a fim de analisar as possibilidades apresentadas pelas narrativas e extrair categorias dessas experiências, que possam apoiar estudos voltados a ambos. Para dar conta dessa condição, no âmbito do texto literário, recorro ao já referido conceito de teor testemunhal, desenvolvido por Márcio Seligmann-Silva, em História, Memória e Literatura: o testemunho na era das catástrofes (2003), defende que para além da existência de uma literatura de testemunho, pensada e expressa sob a alínea do teor de verdade, podemos encontrar também o que ele chama de teor testemunhal, quando a literatura se utiliza de códigos inerentes às formas testemunhais para narrar experiências traumáticas, que desse modo se revestem de um teor de verdade. A fundamentação desse argumento de Seligmann-Silva vem das reflexões de Walter Benjamin em Ensaios reunidos: escritos sobre Goethe, ao definir que:

\footnotetext{
aquela lei fundamental da escrita literária segundo a qual, quanto mais significativo for o teor de verdade de uma obra, de maneira tanto mais inaparente e íntima estará ele ligado ao seu teor factual. Se, em consequência disso, as obras que se revelam duradouras são justamente aquelas cuja verdade está profundamente incrustada em seu teor factual, então os dados do real na obra apresentam-se, no transcurso dessa duração, tanto mais nítidos aos olhos do observador quanto mais se vão extinguindo no mundo. Mas com isso, e em consonância com a sua manifestação, o teor factual e o teor de verdade, que inicialmente se encontravam unidos na obra, separam-se na medida em que ela vai perdurando, uma vez que este último sempre se
}

Revista Moara, n. 56, Vol. 2 jan-jul 2021 ISSN: 0104-0944 
mantém oculto, enquanto aquele se coloca em primeiro plano. Consequentemente, torna-se cada vez mais uma condição prévia para todo crítico vindouro a interpretação do teor factual, isto é, daquilo que chama a atenção e causa estranheza. (BENJAMIN, 2009, p. 12-13)

Saliento que Benjamin observa uma espécie de gradação no texto literário, pois existem obras com maior teor factual, na medida em que agrega fatos presentes no texto, de forma tão evidente e bem articulada, que é capaz de gerar um teor de verdade, que vem a ser aquilo que ultrapassa as relações com a materialidade, relações estas compostas pelos elementos históricos e filológicos. Para Benjamin o teor de verdade resulta do trabalho crítico e é o responsável por produzir a duração da obra. Por isso, como bem pontua Mariana Andrade, ao comentar o ensaio de Benjamin, a elaboração crítica de uma obra faz emergir aquilo que "está para além da sua condição histórica propriamente finita e temporalmente limitada. A crítica, todavia, só consegue realizar essa sua tarefa a partir de uma imersão no teor material para, então, ser capaz de fazer aparecer o teor de verdade" (ANDRADE, 2019, p.139-140)

O raciocínio de Benjamin favorece a observação das nuances, das frestas, bem como suas gradações, que possibilitam ao crítico observar como a obra se reveste com diferentes instâncias de verdade, mesmo que o teor factual seja muito variável e ainda que o teor factual nos possibilite, enquanto leitores, compreender ou não as assimilações direcionadas aos conjuntos do real, apreendidos pela obra. Com a leitura d'As afinidades eletivas de Goethe é possível estender ainda mais a leitura íntima que Benjamin faz da relação entre o factual e o verdadeiro, em que quanto maior a verdade expressa, maior é o facto a sustentá-la.

Desse modo, Márcio Seligmann-Silva afirma que o testemunho também pode ser compreendido por sua dinâmica fundada no factual, pois apresenta uma verdade, marcada pela experiência factual do horror, sujeitada pela impossibilidade de representabilidade gerada pelo trauma. Seligmann-Silva integra ainda ao seu raciocínio a premissa benjaminiana e com base nela postula a necessidade de haver em textos literários uma forma de mediação entre o testemunho e a literatura, ao que vai chamar de teor testemunhal. Nesse sentido,

Ocorre uma revisão da noção de literatura justamente porque do ponto de vista do testemunho ela passa a ser vista como indissociável da vida, a saber, como tendo um compromisso com o real. Aprendemos ao longo do século XX que todo produto da cultura pode ser lido no seu teor testemunhal. Não

Revista Moara, n. 56, Vol. 2 jan-jul 2021 ISSN: 0104-0944 
se trata da velha concepção realista e naturalista que via na cultura um reflexo da realidade, mas antes de um aprendizado - psicanalítico - da leitura de traços do real no universo cultural. Já o discurso dito sério é tragado e abalado na sua arrogância quando posto diante da impossibilidade de se estabelecer uma fronteira segura entre ele, a imaginação e o discurso dito literário. Não existe uma essência do literário que dê conta de contê-lo diante do discurso dito sério. (SELIGMANN-SILVA, 2008, p. 71)

O teor testemunhal apresentado por Seligmann-Silva nos transporta para uma premissa sobre a cultura, também pensada por Benjamin: "nunca houve um documento de cultura, que não fosse um documento de barbárie” (1994, p. 225), justamente porque a cultura não está alheia aos factos e aos eventos catastróficos, pelo contrário, muitas vezes é por meio da cultura e da arte que podemos ter acesso ou mesmo outra leitura acerca das catástrofes. Da mesma forma, o testemunho funciona como uma possibilidade de remoer as imagens tumulares do factual, que precisam emergir. Se encontramos o teor testemunhal na cultura, poderíamos dizer que a literatura, quando se constrói com base nas relações entre o teor de verdade e o teor factual, está repleta de referências da cultura e, por conseguinte, do teor testemunhal. Por essa condição podemos ler os textos literários (também) como testemunhos sobre determinados aspectos que de algum modo marcam uma sociedade. Pensar o factual, como parte de um complexo horizonte de verdades, nos conduz a compreender que tanto o teor de verdade, quanto o teor factual estão imiscuídos do teor testemunhal e o contrário também é válido, por isso na escritura dos textos, volta e meia, nos é possível criarmos relações com a verdade enquanto estatutos testemunhais do factual.

Com base nessas formulações aqui apresentadas faço a seguir a minha contribuição aos estudos da teoria e da história literária: como outra face ou extensão dos estudos sobre as relações entre testemunho e literatura, ao tratar do que passo a chamar de teor ficcional.

Quando defendi minha tese de doutorado intitulada Performance e Testemunho no cinema pós-64, me deparei com o testemunho no cinema e com a dicotomia da relação ficção e realidade e aprendi sobre ela que naquele momento não seria possível pensar adequadamente como superar essa dicotomia, principalmente, porque na época me dediquei ao estudo do documentário e nele o embate relacionado às fronteiras entre 
ficção e realidade são costumeiras e intransponíveis. Depois senti necessidade de pensar sobre isso um pouco mais, uma vez que essa inquietação não ficou restrita àquilo que havia observado na tese, uma vez que passou a percorrer as leituras, a pesquisa e o ensino. Ao ministrar a disciplina Literatura e Testemunho, percebi a oportunidade de voltar novamente a esse debate, na medida em que nas aulas movimentamos os conceitos de verdade e o teor de verdade; testemunho e o teor testemunhal.

Naquele momento, ao ter contato com um corpus diversificado de produções literárias, cinematográficas e testemunhais, observei que no âmbito das narrativas de testemunho, regidas pela experiência de vida de sobreviventes, havia algo tão latente quanto o teor testemunhal, presente em produções artísticas e já amplamente estudado. Algo que na constituição da narrativa de testemunho fazia a sua forma assumir padrões e códigos que a aproximam da ficção, ainda que a narrativa de testemunho não seja verdadeiramente ficção. Foi nesse momento que me surgiu mais claramente a hipótese de que poderíamos estar diante de obras com teor ficcional. O que seria então uma narrativa testemunhal com teor ficcional? Quais características podemos encontrar em uma escrita fundamentalmente comprometida com a verdade, mas que ao se descolar momentaneamente do factual tenta por meio da ficcionalização revestir o testemunho com outros aspectos, que seriam responsáveis por promover a suportabilidade do que está sendo narrado, recuperado, testemunhado?

A literatura de testemunho produzida no século XX apresenta uma forma narrativa particular, que envolve a narração que ora se assemelha, ora se diferencia da ficção e na qual a voz narrativa exerce um importante papel diferenciador e identificador, pois, em geral, temos ora um texto em primeira pessoa, com um narradorpersonagem, autodiegético, superstes; ora temos um narrador em terceira pessoa, heterodiegético, com um eu como testemunha, testis; ora, embora mais raramente, também como um narrador que narra como parceiro na construção da experiência, como segunda pessoa, homodiegético, áudio testemunha, arbiter ${ }^{2}$ :

a narrativa testemunhal apresentará oscilação entre aquele que sobreviveu e narra sua experiência (superstes), o que viu e podia ser visto e narra a experiência do outro, que também é sua (testis), e o que viu e ouviu o

\footnotetext{
2 Esses conceitos foram melhor discutidos em minha tese de doutorado Performance e testemunho no cinema pós-64 e no artigo $O$ testemunho em três vozes: testis, superstes e arbiter.
}

Revista Moara, n. 56, Vol. 2 jan-jul 2021 ISSN: 0104-0944 
sobrevivente ou a testemunha e arbitra uma recepção sobre a cena descrita pelo outro (arbiter). (SARMENTO-PANTOJA, 2016, p. 123)

Ao demarcar estruturalmente esses limites sabemos que no testemunho, muito mais do que na literatura, há fronteiras flexíveis em relação à forma narrativa, principalmente quando se trata de obras literárias escritas segundo modelos clássicos, que, no geral, utiliza-se de apenas uma dessas vozes narracionais. Porém, contemporaneamente, há testemunhos que se utilizam de estratégias bem mais plurais, pondo em xeque o estruturalismo da forma fixa, como acontece com a literatura,

Isso significa dizer que boa parte das produções contemporâneas, entre elas os testemunhos, não se fixam em apenas uma voz narrativa, elas espelham cada vez mais as polifonias descritas por Mikhail Bakhtin. Mesmo quando é possível observar a predominância de uma voz discursiva, como nos testemunhos de Primo Levi, os quais tomei como fundamento para desenvolver o conceito de arbiter, teremos inúmeros momentos em que a narrativa flui para outras vozes, oscilando-as.

O testemunho é marcadamente fixado pelo viés da verdade, da denúncia e da liberdade em relação a eventos históricos, os quais tem urgência de serem narrados, como forma de trazer de volta a integridade perdida em experiências de subjugação, violência física e simbólica, tortura, aniquilamento emocional e físico, morte e desaparecimento. Nesse sentido, Helmut Galle (2018) observa haver uma ficcionalidade específica no testemunho, constituída a partir de um pacto diferenciado. Assim, do mesmo modo que a ficção pode se apropriar dos códigos encontrados no testemunho, o contrário também é possível. Os códigos da ficção também podem estar presentes nos testemunhos e é exatamente sobre isso que me proponho analisar para chegar a uma categorização mais clara do que é o teor ficcional.

\section{$* * *$}

A ficção, pode ser pensada desde Platão, quando em sua República, delega a criação artística ao limbo das coisas não realistas, pois o artista simula a realidade, o que faz dele perigoso para a manutenção da República, baseada nos fundamentos da realidade e da verdade. A ficção, nesse sentido, se aproxima das noções de mentira, ilusão e simulacro, que se tornou na tradição clássica o fundamento do conceito de ficção. Entretanto, Platão também nos mostra que muitas vezes é essa irrealidade que 
potencializa a educação para o medo e a covardia, também condenados por ele, já que a virtude do cidadão deve ser mediada pela coragem e pela virtude. Apesar de na República haver uma visão negativa sobre o artista, já existe no raciocínio de Platão uma função social para o artista e para a arte ficcional, na medida em que ele reclama a responsabilidade do artista pela desmistificação dos deuses e seus usos, ao especular acerca do caráter e da função da invenção e, por conseguinte, da irrealidade, como no diálogo entre Sócrates e Adimanto, primeiramente, no debate sobre a natureza dos deuses:

Tudo o que for de natureza demoníaca e divina é extreme de falsidade.

Tudo, sem dúvida, respondeu.

Logo, Deus é perfeitamente simples e veraz, tanto em atos como em palavras, e não só não muda de forma como não engana os outros por meios ilusórios ou por discursos, nem por sinais de sua parte durante o sono ou na vigília.

É o que também me parece, disse, ao ouvir-te discorrer sobre a matéria. Confessas-te, portanto, de acordo, continuei com o segundo modelo de como se deve falar ou poetar a respeito dos deuses: não são feiticeiros capazes de mudar de forma, nem nos enganam de nenhum jeito, por atos ou por palavras. De acordo. (PLATÃO, 2000, p. 132)

De acordo com esse diálogo, a verdade está naquilo que é sagrado, seja ele demoníaco ou divino, já que na sacralidade não existe espaço para a invenção (ficção/irreal), daí não ser aceitável qualquer formulação que coloque em cheque os poderes mágicos do sagrado. Poderes de transformação e fantasmagoria não deveriam estar ali presentes. Mas sabemos que o valor e o poder dos deuses, os fazem sagrados exatamente pelas ficções que dele emanam, seus poderes, seu antropomorfismo é que o diferenciam dos homens. No texto de Platão, os deuses não seriam superiores por estarem no âmbito do fantasmático, mas pela nobreza e pela verdade que os constitui. E os homens deveriam aprender essa lição com eles. De outro modo, a aceitação do contrário como invenção, leva à reflexão sobre a natureza da verdade, sendo esta intrínseca ao sagrado e distante do artístico. Ainda considerando o diálogo anteriormente citado trago também a reflexão de Sócrates sobre esse aspecto:

\footnotetext{
Assim, conquanto elogiemos muita coisa em Homero, não louvaremos nele o sonho enviado a Agamémnone por Zeus, como não louvaremos Ésquilo na passagem em que Tétis diz que Apolo cantara no seu casamento, prometendo-lhe

... feliz maternidade, filhos sadios e de vida longa Essas palavras foram reforçadas
}

Revista Moara, n. 56, Vol. 2 jan-jul 2021 ISSN: 0104-0944 


\begin{abstract}
pelo peã por ele decantado
para me encorajar, e em que exaltava

meu destino abençoado pelos deuses.

Pensei que sua boca fosse extreme,

de qualquer inverdade, porque manan

sempre dela os oráculos. No entanto,

muito embora ele próprio assim falasse,

autor, como era, do hino, e no banquete

se encontrasse presente, ele, ele próprio,

foi quem matou meu filho.
\end{abstract}

Censuraremos o poeta que se referir aos deuses por esse modo e não lhe concederemos coro; outrossim, não permitiremos que os professores empreguem suas composições na educação dos moços caso queiram que nossos guardas fiquem piedosos e - tanto quanto o permitir a natureza humana - semelhantes aos deuses. (PLATÃO, 2000, p. 132-133)

O trecho especula sobre como a condição fantasmática do sonho e do sagrado tolda e encobre a factualidade no texto de Homero, da mesma forma como faz Plauto em sua comédia Anfitrião, para justificar um filho fora do casamento. Ainda na Ilíada, Homero revela que o Apolo (Febo) engana Tétis, sobre a longevidade de Aquiles e acusa o deus de ser o responsável pela morte do venturoso guerreiro, quando antes teria afirmado sua longa existência. O problema para Platão se dá, portanto, quando a representação substitui a nobreza e a verdade pelo encobrimento de outros caracteres, próprios dos homens. Essa mesma condição fantasmática inerente ao uso da sacralização também cria outras formulações da verdade, como a lenda do boto, na Amazônia, quando o sagrado é demoníaco e sob a égide do insólito e do irreal se torna responsável por encobrir o que acontece quando nascem crianças fora do laço legítimo do matrimônio ou são produtos do abuso sexual contra mulheres.

Quando não é conveniente trazer à tona os erros humanos na sua execrável factualidade estes são revestidos pelas atribuições do sagrado, seja ele divino ou demoníaco em seus desígnios. Desse modo, o parêntese sobre o trabalho de Platão na percepção da arte literária, acusada de ser um simulacro do real capaz de encobrir ou perverter a realidade, realça uma questão de fundo, que de certo modo também mobiliza o problema aqui levantado: é pior a verdade sobre o futuro trágico ou a ficcionalização do trágico heróico? Em outras palavras: pensar sobre a verdade da ficção nos impele a pensar sobre o que se narra, as escolhas que fazemos, os posicionamentos que precisamos tomar e o teor de verdade que se quer implicar naquilo que é narrado.

Juan José Saer, em interessante ensaio, intitulado $O$ conceito de ficção, salienta que a "verdade não é necessariamente o contrário de ficção e que, quando optamos pela Revista Moara, n. 56, Vol. 2 jan-jul 2021 ISSN: 0104-0944 
prática da ficção, não o fazemos com o propósito turvo de tergiversar a verdade." (SAER, 2012, p. 2), colaborando assim com o argumento direcionado à coexistência entre ficção, verdade e realidade. Sobre a realidade, o ensaio $O$ efeito de realidade e a política de ficção, de Jacques Rancière, também se direciona por esse mesmo caminho e acrescenta que "o efeito de realidade rompe com a lógica da representação. Mas ele o faz implementando uma estratégia intermediária: conforme toma o princípio "realista" da história, agarrando-se ao real enquanto real, ele cria um novo tipo de verossimilhança" (2010, p. 76).

O já clássico ensaio $O$ efeito do Real, de Roland Barthes é outro texto em que encontro importantes formulações que norteiam a constituição daquilo que proponho como teor ficcional:

\begin{abstract}
A resistência do real (sob sua forma escrita, bem entendido) à estrutura é muito limitada no discurso narrativo fictício, construído por definição sobre um modelo que, em grandes linhas, não tem outras restrições que não as do inteligível; mas esse mesmo 'real' torna-se a referência essencial no discurso narrativo histórico, que é suposto relatar 'o que realmente se passou': que importa então a não-funcionalidade de um detalhe, uma vez que ele denota 'o que já ocorreu': o 'real concreto' torna-se a justificação suficiente do dizer. (BARTHES, 1972, p. 41)
\end{abstract}

Voltado especificamente aos estudos do testemunho, destaco o ensaio $O$ testemunho: um novo paradigma da ficção, de Helmut Galle, dedicado àquilo que ele chama de "pacto testemunhal", assim definido: "[...] o pacto testemunhal sugere que o autor se compromete com a autenticidade da experiência narrada no texto, independentemente de as proposições serem referenciais" (GALLE, 2018, p. 177-178). Desse modo, o texto "[...] deve ser lido como representação parcial e subjetiva do Holocausto. Ele reclama ser entendido como relato autêntico, com as licenças sancionadas pela fragmentariedade da percepção, pela fragilidade da memória, pelas limitações da linguagem e pela interpretação subjetiva de cada autor" (Idem, p.178)

Quando penso no texto literário, por conta do tal pacto ficcional, avalio que somos levados a compreender o quanto o leitor constrói essa resistência do real. Por isso, o conceito de verossimilhança é tão caro à narrativa literária, que em várias situações da escrita literária o pacto com o leitor, que fundamenta a verossimilhança, se reveste (na e) da narrativa histórica, justamente por estar embebido pelos elementos factuais de uma dada época, como vemos, por exemplo, nos romances históricos ou nas 
metaficções historiográficas. Nesses casos, o romance histórico é sempre visto como a forma ficcional mais inclinada a se apropriar das nuances do real. Ressalto ainda que no âmbito da crítica literária contemporânea o poder do termo "histórico", associado ao real, vem sendo constantemente utilizado para constituir ora com maior verossimilhança aquilo que é narrado, ora para dar à ficção um maior poder revisionista sobre determinada sociedade.

Contudo, seja qual for o paradigma de representação da realidade ou da forma ficcional, a verossimilhança é sem dúvida um estatuto fundante no campo literário e definitivamente não são as gradações de maior ou menor proximidade com os elementos factuais o que vai determinar se um texto literário possui mais verossimilhança que outro. Da mesma forma que não são as gradações de maior ou menor presença de elementos ficcionais em um texto não-literário que vão colocar em xeque o seu status de documento ou testemunho.

Podemos tomar como exemplo um texto de ficção científica, que pelo estatuto ficcional representaria um universo irreal, mesmo que essa irrealidade seja real em algum canto do planeta, mesmo quando a narrativa é de outro planeta. Ou seja, mesmo diante do irreal buscamos construir as ligações para encontrar verossimilhança no percurso narrado.

Da mesma forma que seria irreal encontrar um caso rosiano como o desenvolvido em Desenredo, conto que apresenta um enredo ambientado em uma cidade pequena do interior do Brasil, onde, em geral, todos sabem tudo o que acontece com todos e os códigos sociais são organizados e policiados pela bisbilhotice. Somente mediante o pacto ficcional seria possível convencer o leitor de que uma mulher confessadamente adúltera, nunca, em hipótese alguma, teria traído, pois um dos homens traídos não vê alternativa para sua vida, se não viver com a mulher que sempre amou mesmo que os códigos sociais cobrem dele outra escolha. Entretanto, esses casos ocorrem constantemente na vida real, com cores e sabores diferentes e estão nos jornais, nas revistas, na internet, nos aplicativos, criados e recriados pelo mundo real ou virtual. Por sinal, no mundo contemporâneo a virtualidade é um dos grandes protagonistas da ficcionalização generalizada, as chamadas Fake News, em que as falsas notícias vão se espalhando, sem que seja verificado seu teor factual.

Revista Moara, n. 56, Vol. 2 jan-jul 2021 ISSN: 0104-0944 
Embora o conceito de Fake News (falsas notícias) seja recente, a prática de fazer circular notícias sobre situações inventadas ou mentirosas não é uma criação moderna. Algumas delas ficam fixadas como verdades absolutas. Na história da sociedade brasileira temos vários exemplos de como o autoritarismo dos povos dominadores se utilizaram de ficções ou do teor ficcional na formalização dos acontecimentos, para construir a matéria da chegada dos portugueses às Terras de Vera Cruz. Vamos a um exemplo clichê encontrado no primeiro texto oficial sobre o Brasil. A Carta, que Pero Vaz de Caminha escreveu ao rei Dom Manoel para apresentá-lo a viagem às Índias e que levou os navegadores portugueses a invadir a Terra de Vera Cruz. Medindo as proporções, nesse texto, encontramos as primeiras Fake News sobre o Brasil. Vejamos um trecho dela, que claramente apresenta o interesse de convencer o rei português que a nova terra e seus habitantes aceitaram pacificamente a exploração:

Dali avistámos homens que andavam pela praia, obra de sete ou oito, segundo disseram os navios pequenos, por chegarem primeiro.

Então lançámos, fora os batéis e esquifes; e vieram logo todos os capitães das naus a esta nau do capitão-mor, onde falaram entre si.

E o capitão-mor mandou em terra no batel a Nicolau Coelho para ver aquele rio. E tanto que ele começou de ir para lá, acudiram pela praia homens, quando aos dois, quando aos três, de maneira que, ao chegar o batel à boca do rio, já ali havia dezoito ou vinte homens.

Eram pardos, todos nus, sem coisa alguma que lhes cobrisse suas vergonhas. Nas mãos traziam arcos com suas setas. Vinham todos rijamente sobre o batel; e Nicolau Coelho lhes fez sinal que pousassem os arcos. E eles os pousaram. (CAMINHA, 1500, p. 2)

O texto, o narrador indica a clara superioridade dos portugueses que subjugam os nativos, valendo-se da trapaça, pois os usurpadores da terra agem como se fossem amigos, ao ponto de mesmo sem a possibilidade do diálogo por conta do desconhecimento do idioma, com um mero sinal, foram capazes de desarmar os guerreiros. Essa é a primeira, mas não única, nem a maior das Fake News, que ainda se encontram nos manuais escolares, mesmo depois de 520 anos da expedição e da farsa de que a invasão das terras latino-americanas não passaram de um acaso e que os invasores não encontraram resistência ao extermínio imposto às sociedades que viviam nessas terras. A história portuguesa endossou a Carta como documento, recheado de situações mediadas pela invenção, bem distante da realidade.

Ao transformar-se em um misto de documento e literatura, o texto da Carta envereda para a ficcionalização dos acontecimentos narrados por via do anedótico e de

Revista Moara, n. 56, Vol. 2 jan-jul 2021 ISSN: 0104-0944 
um colorido maravilhamento. A realidade estetiza-se, portanto, a serviço de mostrar a pacificação e, sobretudo, o assujeitamento da alteridade, registrada pelo missivista, que expressa o anseio do conquistador em detrimento da realidade da conquista. $O$ documento, deixa-se impregnar de um teor ficcional ao narrar um encontro deveras conflituoso, mas sem conflito, sem derramamento de sangue, sob os signos da heroicização e de uma superioridade portuguesa, que elegeu Pedro Álvares Cabral a grande figura desta história.

Desse modo, proponho o teor ficcional como possibilidade para o testemunho assumir no todo ou em parte a apropriação de elementos estéticos, estratégias ou técnicas pertencentes à ficção. O teor ficcional, contudo, não se restringe ao manuseio de códigos ou elementos estéticos capazes de impor ao texto um filtro ficcionalizante, os códigos ou elementos utilizados nesse filtro também devem estar diretamente ligados aos interesses do narrador e, em muitos casos, às necessidades do narratário, pois o texto é para alguém, se destina a um público. Nesse sentido, o teor ficcional pode ser fundamental para que o pacto entre aquele que narra e aquele que recebe a narrativa, seja efetivado.

Em muitas dessas situações, se o documento ficcionaliza uma determinada realidade, submetendo-a ao realismo da voz autoritária, a ficção pode vir a devolver a quem compete as verdades sequestradas. O Karaíba, romance de 2010, de Daniel Munduruku, nos apresenta uma formulação ficcional de como um velho Karaíba entende a profecia sobre a chegada dos portugueses a seu mundo - porque afinal não existe uma "história" da terra "descoberta" antes da Carta, mas o romance se vale das cosmogonias oriundas dos povos originários e nelas se baseia para compreender a invasão, vista sob a égide da catástrofe:

Lembrou do velho Karaíba, que havia passado por sua aldeia a pouco tempo e tinha dito coisas assustadoras que aconteceriam dentro em breve. Entre elas, disse que aquele mundo conhecido por todos acabaria e tudo seria destruído pela passagem de um grande monstro vindo de outros cantos.

Ele disse:

- Minhas visões trazem sinais terríveis. Não sobrarão nem vestígios de nossa passagem sobre essa terra onde nossos pais viveram. Os monstros virão e destruirão nossas memórias e nossos caminhos. Tudo será revirado: as águas, a terra, os animais, as plantas, os lugares sagrados. Tudo. (MUNDURUKU, 2010, p. 2)

Revista Moara, n. 56, Vol. 2 jan-jul 2021 ISSN: 0104-0944 
O texto de Munduruku, revestido de uma memória ancestral, escrito 510 anos depois da Carta de Caminha, nos apresenta uma pré-história do Brasil, que não teria como estar presente na Carta e que contradiz aquele discurso de que os povos originários aceitaram com passividade e subjugação a conquista dos invasores. De outro modo, essa perspectiva não poderia estar em um texto como produto da visão do Karaíba, posto que, até onde sabemos, não havia escrita por essas paragens, nem documentos e se existiam, não temos acesso, nem aos seus rastros, pois a destruição etnocida e culturicida em massa inviabilizou o contato com inúmeras verdades provenientes dos saberes desses povos, dos caminhos que traçaram e de muitas outras coisas. O que nutre, portanto, a narrativa do romance é uma ancestralidade que ultrapassa a própria noção de documento, convertida em memória.

Assim como a Carta de Caminha contém teor ficcional, o romance O Karaíba, por tudo isso, poderia ser lido como um tex to literário com teor testemunhal, pois traça em sua narrativa o percurso historiográfico de uma história, que até poderia ser contada pelos portugueses, mas não havia interesse algum nisso, pois até aprenderam a língua e conheceram a cultura, mas optaram por às aniquilar. E como se vê na Carta, o opressor quando conta a história dos subalternizados, quase sempre o faz segundo a sua perspectiva assujeitadora. Só quem viveu e sofreu o aniquilamento teria condições de narrar, de recuperar o passado de um modo mais compatível com a verdade. De outro modo, poderíamos dizer que o texto de Munduruku, arquetipicamente, percorre uma possibilidade de testemunho através de sua ancestralidade e, sendo assim, temos em seu texto também um teor ficcional, se tomarmos como referência que os antepassados iluminam sua escrita com seus saberes e trazem para o texto os códigos do testemunho de um passado que habita o imaginário, transmitido de geração em geração.

Daniel Munduruku concebe $O$ Karaíba não com a intenção de escrever um documento histórico, mas com o intuito de escrever um romance, marcadamente arbiter - porque de outro modo não seria possível - e revelador de uma narrativa geracional, pois os saberes que nela repercutem estão de algum modo gravados na memória de seu povo, tornando-se aquela verdade que o texto deixa claro em sua abertura: "esta é uma história de ficção. Não aconteceu de verdade, mas poderia ter acontecido" (MUNDURUKU, 2010, p. 95). Nesse sentido, a ficção assevera um teor testemunhal, pois mesmo assumindo-se como ficção constitui-se como um testemunho amparado por

Revista Moara, n. 56, Vol. 2 jan-jul 2021 ISSN: 0104-0944 
uma memória geracional, que por sua vez não deixa de se valer do teor ficcional, posto que o seu teor de verdade se fundamenta em uma experiência de sobrevivência, baseada naquilo que poderia ter sido enquanto dado factual. Há, portanto, um intercâmbio dos códigos que envolvem o circuito entre testemunho e literatura nesse romance de Munduruku, que certamente permite compreender como se estabelecem as diferenças e as frestas - entre o teor testemunhal e o teor ficcional em uma mesma narrativa.

O romance nos mostra que não havia um povo pacífico, pronto para ser dominado pelo invasor, pelo contrário, a obra nos apresenta a necessidade de mudar uma cultura de dois povos rivais em nome da sobrevivência, para que unidas pudessem gerar um fio de esperança e resistência, o nascimento do escolhido, que será responsável por liderar os povos para lutar contra os fantasmas:

\footnotetext{
Um dia Cunhambebe andava pelas margens do paranã coletando conchas quando lhe chamou atenção um ponto branco que 'surfava' sobre as águas salgadas. O jovem se assustou com aquela visão e saiu correndo, largando o fruto do seu trabalho no chão. Sua gritaria chamou a atenção de todas as pessoas da aldeia, que se reuniram para ouvir o que o escolhido tinha para dizer. Sem fôlego devido a sua forte correria, o garoto respirou fundo e gritou:

- Os fantasmas estão chegando! Os fantasmas estão chegando! (MUNDURUKU, 2010, p. 93-94)
}

Mas, ao que parece, o Cunhambebe do romance de Daniel Munduruku, apesar de ser o escolhido, ainda não tinha como evitar o aniquilamento de seu povo, ainda que seja anunciado como uma possibilidade de resistência para o futuro, sem sombra de dúvidas!

$* * * *$

Chego até aqui seguindo o argumento em torno das frestas, que separam a compreensão tanto da ficção, quanto do testemunho, por meio de um amálgama narrativo, responsável por sinuosidades de um no outro.

Acompanho Galle em sua proposição de que, enquanto gênero, o testemunho mostra "particularmente sua qualidade de transcender a fronteira discursiva entre ficção e não ficção que levanta a hipótese de se tratar de um fenômeno que está afetando nosso conceito "tradicional" de ficcionalidade" (GALLE, 2018, p. 168). Proponho que da 
mesma forma que encontramos o teor testemunhal, na ficção, quando esta se utiliza de códigos muito próximos aos de um testemunho, como as repetições, as elipses, a necessidade do critério da evidência ao inserir elementos de veridição, o tom de depoimento, entre outras, é possível tomarmos o teor ficcional como uma categoria possível e imanente à teoria do testemunho e formas correlatas.

Por ser produto de uma experiência pessoal e particular, o testemunho não escapa à subjetivação. Por isso, é sempre possível observar na narrativa do testemunho a afetação da técnica narrativa da ficção, sobretudo, para dar conta das situações narradas, que pelo nível de insuportabilidade, precisam ser constituídas de outros modos, daí a presença do teor ficcional no testemunho. Em causa está a potência da linguagem para a empatia, para a constituição da responsabilidade para com o outro.

A seguir, faço a análise de várias passagens para mostrar como o conceito de teor ficcional pode ser compreendido, especialmente no testemunho de sobreviventes da Shoah, marcado por uma forte necessidade de narrar o trauma, amalgamado pela reflexão sobre a condição humana e que diante da insuportabilidade dos eventos vividos pelo testemunhador. Essas narrações, se constituem em autênticas ferramentas do que Seligmann-Silva chama de "condição de sobrevivência", que faz com que o ato de testemunhar seja uma necessidade vital, como comer, beber, dormir.

Tomo como exemplo o texto mais emblemático do testemunho da Shoah, o livro É isto um homem, de Primo Levi. A potência de sua escrita revela muito bem um projeto editorial, que associa testemunho e literatura, isso porque ele usa as estratégias do poético e do literário em vários momentos, desde a escolha de alguns títulos para os capítulos que conduzem o relato, até o uso de formas e estratégias que são claramente oriundos das formas poéticas. Vejamos o capítulo, que dá título à obra e ao mesmo tempo serve para abrir o testemunho: trata-se de um poema, ao modo moderno dos versos livres e brancos, intitulado "Vocês que vivem seguros":

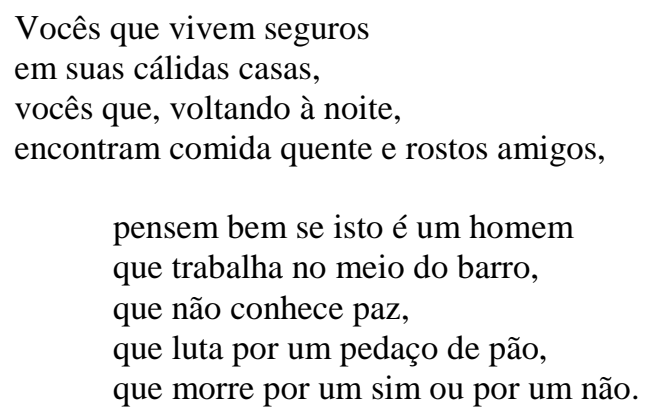

Revista Moara, n. 56, Vol. 2 jan-jul 2021 ISSN: 0104-0944 
Pensem bem se isto é uma mulher, sem cabelos e sem nome, sem mais força para lembrar, vazios os olhos, frio o ventre, como um sapo no inverno.

Pensem que isto aconteceu:

eu lhes mando estas palavras.

Gravem-na em seus corações, estando em casa, andando na rua, ao deitar, ao levantar; repitam-nas a seus filhos.

Ou, senão, desmorone-se a sua casa, a doença os torne inválidos, os seus filhos virem o rosto para não vê-los. (LEVI, 1988, p. 9)

O uso do imperativo "pensem" é fundamental para mostrar um eu-lírico preocupado em se fazer ouvir diante dos horrores que serão narrados. Seu testemunho versa sobre um medo latente dos sobreviventes: "aos seus filhos virem o rosto para não vê-los" (Ibidem), não ouvi-los, não respeitá-los.

Outro capítulo instigante para refletirmos sobre o âmbito de ocorrência do teor ficcional e poético no testemunho de Levi é o "O canto de Ulisses", que conta o seu contato com o jovem Häftling ${ }^{3}$ do Kommando ${ }^{4}$ Químico, Jean, e a experiência em se tornar amigo do Pikolo $^{5}$ do Kapo $^{6}$ e a aventura de ensinar o italiano, por meio de

\footnotetext{
3 Oliver Lustig, no Concentration Camp Dictionary, apresenta entre outras definições: “A man taken from among the people and interned in a Nazi concentration camp. A man that was no longer considered as such. A man who was annulled all rights. The right to love, to have a family, to walk, to have memories. The right to think, to protest, to act. The right to have a name". Em português, traduziria: "Um homem retirado do meio do povo e internado em um campo de concentração nazista. Um homem que não era mais considerado como tal. Um homem que foi anulado todos os direitos. O direito de amar, de ter uma família, de caminhar, de ter lembranças. O direito de pensar, protestar, agir. O direito de ter um nome." Disponível em: https://isurvived.org/Lustig_Oliver-CCDictionary/CCD-06_HI.html\#B2

${ }^{4}$ Segundo Holocaust Encyclopedia, "Kommando: German word for detachment, such as a detachment of concentration camp prisoners at forced labor". Em português, traduziria: "Kommando: palavra alemã para desapego, como um destacamento de prisioneiros de campos de concentração em trabalhos forçados" Originalmente publicado em inglês, no site United States Holocaust momorial Museum: https://encyclopedia.ushmm.org/content/en/article/glossary

${ }^{5}$ Levi descreve as atribuições de Jean, com "a função de Pikolo: de mandalete-escriturário, encarregado de limpar o barraco, entregar as ferramentas, lavar as gamelas, ter a contabilidade das horas de trabalho no Kommando (...) está isento do trabalho braçal, tem livre acesso ao fundo do panelão do rancho, pode ficar o dia todo perto da estufa; portanto tem direito a meia ração suplementar, boas chances de tomar-se amigo e confidente do Kapo, do qual recebe oficialmente as roupas e os sapatos velhos" (LEVI, 1988, p. 111-112),

6 Segundo Holocaust Encyclopedia, "Kapo: a concentration camp prisoner selected to oversee other prisoners on labor details. The term is often used generically for any concentration camp prisoner to whom the SS gave authority over other prisoners.". Tradução minha: "Kapo: é um prisioneiro de um campo de concentração selecionado para supervisionar outros prisioneiros em destacamentos de trabalhos forçados. O termo é usado para descrever qualquer prisioneiro que recebeu alguma autoridade sobre
}

Revista Moara, n. 56, Vol. 2 jan-jul 2021 ISSN: 0104-0944 
passagens da Divina Comédia, uma clara referência e depois, citação literária no testemunho:

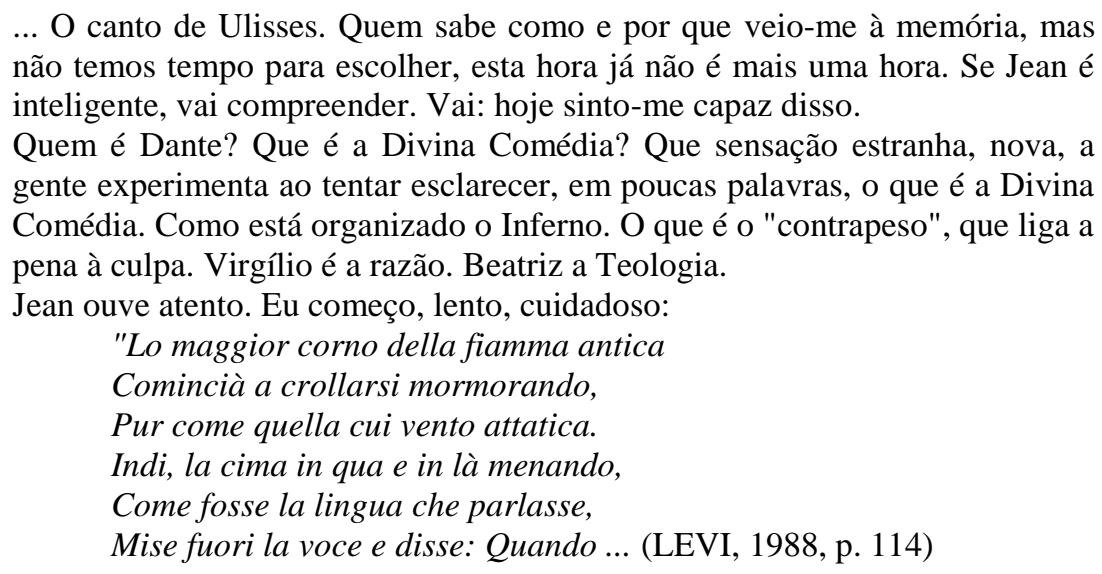

Certamente o teor ficcional não se reduz ao uso de referências e apropriações da forma literária. Há testemunhos que o expressam ao manusear elementos e estratégias mais sutis.

$\mathrm{Na}$ maioria das narrativas de testemunho é possível encontrar um trabalho narrativo fixado em trazer à tona a memória do fato, da verdade do testemunhador sobre o evento. Isso faz com que a narração tenha um ritmo mediado pela sequência dos acontecimentos narrados. A escrita ou a fala sobre suas experiências não são contínuas, nem organizadas. No geral, essa organicidade será costurada pelo projeto editorial do testemunho. Entretanto, durante a construção do testemunho nos deparamos com passagens que fogem a esse princípio e enveredam por outras estratégias narrativas, como ocorre no início do texto de Levi. Nele encontramos uma importante preocupação em refletir sobre a condição humana, na medida em que o narrador aprofunda a introspecção e a linguagem envereda pelo fluxo de consciência. A seguir, uma das muitas passagens que exemplifica essa organicidade:

Cedo ou tarde, na vida, cada um de nós se dá conta de que a felicidade completa é irrealizável; poucos, porém, atentam para a reflexão oposta: que também é irrealizável a infelicidade completa. Os motivos que se opõem à realização de ambos os estados-limite são da mesma natureza; eles vêm de nossa condição humana, que é contra qualquer "infinito". Assim, opõe-se a esta realização o insuficiente conhecimento do futuro, chamado de esperança no primeiro caso e de dúvida quanto ao amanhã, no segundo. Assim, opõe-se a ela a certeza da morte, que fixa um limite a cada alegria, mas também a cada tristeza. Assim, opõem-se às inevitáveis lides materiais que, da mesma

outros prisioneiros pelos SS. Originalmente publicado em inglês, no site United States Holocaust momorial Museum: https://encyclopedia.ushmm.org/content/en/article/glossary

Revista Moara, n. 56, Vol. 2 jan-jul 2021 ISSN: 0104-0944 
forma como desgastam com o tempo toda a felicidade, desviam a cada instante a nossa atenção da desgraça que pesa sobre nós tornando a sua percepção fragmentária, e, portanto, suportável. (LEVI, 1988, p. 15)

O narrador converge o fluxo narrativo para especular sobre questões interiores e ontológicas, tal como a vida, a morte, a felicidade, a infelicidade, o presente e o futuro, entre outras questões que remetem a análise da condição humana diante de experiências- limites e inclassificáveis, como a Shoah. Esse procedimento se torna recorrente na medida em que a matéria da narração vai se tornando insuportável. Ou naqueles momentos em que todos os horizontes de expectativa sobre o futuro se tornam totalmente inseguros. Ou quando é preciso refletir sobre o caráter absurdo e escatológico da situação vivida. Ou ainda quando a testemunha se vê diante da percepção de um hoje e um amanhã cada vez mais fragmentados. Em termos estéticos essas reflexões não se limitam ao fluxo de consciência, elas também se planificam como meta-reflexão:

\begin{abstract}
Imagine-se, agora, um homem privado não apenas dos seres queridos, mas de sua casa, seus hábitos, sua roupa, tudo, enfim, rigorosamente tudo que possuía; ele será um ser vazio, reduzido a puro sofrimento e carência, esquecido de dignidade e discernimento - pois quem perde tudo, muitas vezes perde também a si mesmo; transformado em algo tão miserável, que facilmente se decidirá sobre sua vida e sua morte, sem qualquer sentimento de afinidade humana, na melhor das hipóteses considerando puros critérios de conveniência. (LEVI, 1988, p. 25)
\end{abstract}

Levi, nesta passagem, ao proporcionar uma sensação de compartilhamento das emoções e das frustrações, tenta atrair a atenção do leitor para a matéria narrada e para a própria condição narrativa. Pede para que o leitor sinta como o narrador superstes sentiu o esvaziamento do corpo e da alma diante das privações de direitos fundamentais, fazendo-nos entender a pergunta-título de seu testemunho: é isto um homem? Pensar sobre a humanidade, em um texto fundado no questionamento da condição humana, é mais que um simples comentário meta-reflexivo, pois perpassa por apresentar ao leitor uma ferramenta narrativa poderosa, que o transporta para aquela realidade, como ele o faz:

\footnotetext{
... Este ano passou depressa. No ano passado, a esta hora, eu era um homem livre; fora da lei, porém livre, tinha nome e família, uma mente ávida e inquieta, um corpo ágil e saudável. Pensava em muitas coisas, todas tão longínquas: no meu trabalho, no fim da guerra, no bem e no mal, na natureza das coisas e nas leis que regem as ações humanas e também nas montanhas, em cantar, no amor, na música, na poesia. Tinha uma imensa, arraigada, tola confiança na benevolência do destino; matar, morrer pareciam-me coisas
}

Revista Moara, n. 56, Vol. 2 jan-jul 2021 ISSN: 0104-0944 
estranhas, literárias. Os meus dias eram alegres e tristes, mas eu tinha saudade de todos eles, todos eram cheios, positivos, o futuro estava à minha frente como um tesouro. De minha vida de então, só me resta o que basta para sofrer a fome e o frio; já não sou vivo o bastante para ter a força de acabar comigo. (LEVI, 1988, p. 145)

Ao trazer à baila as frustrações sobre a crueldade e a injustiça extremas, que nos parecem intermináveis, a narrativa nos permite entender o processo de aniquilamento vivido por Primo Levi e por milhares de sobreviventes da Shoah. Por isso, e por conta do apego às bases religiosas do judaísmo, o narrador fica impedido de se entregar à morte, ao suicídio. Sem dúvida, ter se encontrado com a face mais grotesca do mal que o cercava, foi um dos grandes choques sofridos pelos sobreviventes dos campos de extermínio. Daí a profunda necessidade de metaforização e/ou alegorização da realidade, expressa principalmente por meio de uma paisagem estetizada, como vemos na passagem a seguir:

Ao redor de nós, tudo nos é hostil. Por cima, sucedem-se maldosas nuvens para tirar-nos o sol; por todos os lados, circunda-nos a esquálida floresta de ferro retorcido. Nunca vimos seus limites, mas sentimos, ao redor, a presença má do arame farpado que nos segrega do mundo. E nos andaimes, nos trens manobrando, nas estradas, nas escavações, nos escritórios, homens e homens, escravos e patrões, e os patrões, escravos eles também; o medo impele uns e o ódio os outros; qualquer outra força emudece. Todos são, para nós, inimigos ou rivais. (LEVI, 1988, p. 41; grifos meus)

A "esquálida floresta de ferros retorcidos" representa a dimensão do horror e a magnitude da hostilidade sentida em Auschwitz, Belzec, Sobibor, Treblinka, entre outros espaços de aniquilação. Ela sintetiza passagens em que as vítimas se encontram cercadas ora por inimigos, ora por rivais e cobertas pela iminência da morte terrível.

Da perspectiva narratológica, penso que é nessa estetização da coisa vivida, sob forte mediação semiótica, que o testemunho reverbera o teor ficcional. Assim, na escrita de Primo Levi o narrador traz até nós a experiência vivida, através do filtro focalizador da onisciência seletiva, a fim de dar conta também das particularidades inerentes ao pensar e ao sentir dos personagens ali narrados. Vejamos como Alberto será apresentado por Levi:

\footnotetext{
Alberto é o meu melhor amigo. Tem apenas vinte e dois anos (dois menos que eu), mas nenhum de nós, italianos, revelou capacidade de adaptação semelhante à dele. Alberto entrou no Campo de cabeça erguida e vive no Campo ileso, íntegro. Foi o primeiro a compreender que esta vida é uma guerra; não fez concessões a si mesmo, não perdeu tempo com recriminações
}

Revista Moara, n. 56, Vol. 2 jan-jul 2021 ISSN: 0104-0944 
ou compadecendo-se de si próprio e dos outros; foi à luta desde o primeiro dia. Ajudam-no sua inteligência e sua intuição; raciocina e acerta; às vezes não raciocina, e acerta também. Percebe tudo num instante; fala apenas um pouco de francês, mas compreende o que lhe dizem alemães e poloneses. Responde em italiano e, com gestos, se faz compreender e se torna simpático a todos. Luta pela vida, mas é amigo de todos. "Sabe" quem subornar, quem evitar, quem poderá mover-se à compaixão, a quem se deve resistir. (LEVI, 1988, p. 57; grifos meus)

Se o que Levi nos revela é resultado de confidências de Alberto, porque não nos diz exatamente que se tratam de confidências? Nos parece, assim, bem mais o caso em que o testemunho se reveste do teor ficcional. No breve passeio que Levi faz ao universo introspectivo de Alberto revela muito bem que o testemunho ali proposto não seria possível se não fosse arbiter, pois conhecer os íntimos pensamentos e a forma de raciocinar do amigo, perpassa por algo além da observação e do conhecimento de um determinado cotidiano. Perpassa pela reflexão a fundo sobre os modos de ser da existência na exceção e Levi quer valorizar o modo particular como cada indivíduo vive essa experiência, por isso, a sua narração, ao falar de Alberto, assume-se como onisciência seletiva, estratégia que se torna ainda mais saliente em função do uso do discurso indireto livre. Contudo, tanto a onisciência seletiva, quanto o discurso indireto livre são estratégias ficcionalizantes, por isso podemos dizer que Alberto se dilui como amigo confidente e ganha força como personagem, porque para refletir sobre a existência na exceção não basta apenas relatar as atrocidades ou descrever a paisagem, é preciso projetar a perspectiva de quem a viveu. É preciso assumir o testemunho enquanto arbiter. E isso significa, sobretudo, selecionar e salientar. Significa, também, que para o narrador do testemunho falar da experiência do outro na condição de testemunha solidária, é preciso ir dentro do ser, e ir dentro do ser quando não é o seu próprio eu, acaba por constituir o outro como personagem.

Penso que a busca da potência para a empatia no testemunho de Primo Levi nos permite encontrar espaço para a imaginação e o onírico, que também podem se revelar como outra faceta das estratégias ficcionais possíveis de estarem presentes no testemunho do sobrevivente. Cito uma dessas passagens:

O sonho está na minha frente, ainda quentinho; eu. Embora desperto, continuo, dentro, com essa angústia do sonho; lembro, então, que não é um sonho qualquer; que, desde que vivo aqui, já o sonhei muitas vezes, com pequenas variantes de ambiente e detalhes. Agora estou bem lúcido, recordo também que já contei o meu sonho a Alberto e que ele me confessou que esse

Revista Moara, n. 56, Vol. 2 jan-jul 2021 ISSN: 0104-0944 
é também o sonho dele e o sonho de muitos mais; talvez de todos. Por quê? Por que o sofrimento de cada dia se traduz, constantemente, em nossos sonhos, na cena sempre repetida da narração que os outros não escutam? (LEVI, 1988, p. 60)

No excerto, Levi nos apresenta uma reflexão muito interessante sobre o papel dos sonhos na psiquê dos sobreviventes e como o sonho se torna uma metáfora da resistência e da necessidade de narrar, que envolve ao mesmo tempo uma memória individual e coletiva. Mas o sonho, para Levi, terá muito mais expressividade na medida em que ele o apresenta como uma formulação do teor ficcional, através do uso de recursos como o flashforward, uma estratégia de digressão narrativa fundada na antecipação de uma ação futura, quebrando a cronologia narrativa. Passo ao exemplo no texto de Levi:

Então aconteceu algo importante, vale a pena contá-lo agora, talvez pela mesma razão pela qual valeu a pena que acontecesse, naquele dia. Ocorreume fazer um longo discurso a Kraus, em mau alemão, porém devagar, palavra por palavra, procurando estar certo, depois de cada frase, de que ele tivesse compreendido.

Contei que sonhara estar na minha casa, na casa onde nasci, sentado junto com a minha família, com as pernas embaixo da mesa e, na mesa, muita, muitíssima comida. Era verão, na Itália. Em Nápoles? Pois sim, em Nápoles, não vamos complicar. Tocou a campainha, eu levantava ansioso, abria a porta, e quem aparecia? Ele, o nosso Ktaus Páli, com seus cabelos, limpo, gordo, numa roupa de homem livre e com um pão na mão - um pão de dois quilos, ainda quentinho. Então, Servus, Páli, wie geht's? (Oi, Páli, como é que vai?), e eu me sentia feliz, fazia-o entrar, explicava aos meus familiares quem era, que ele vinha de Budapeste e por que estava tão molhado. E davalhe de comer e de beber, e logo uma boa cama para dormir, e era noite, mas havia um calor maravilhoso, num instante ficávamos secos, eu também que, como ele, tinha estado bem molhado. (LEVI, 1988, p. 136)

A esperança de ter um futuro naquele momento era algo improvável, deveria ser resultado apenas dos desejos interiores formulados por meio dos sonhos. Desejos que o testemunho só permitiu que fosse narrado por conta do fim da guerra e da experimentação de um presente, que se não igual se aproxima daquele idealizado. Portanto, o tempo da narração é parte das escolhas sobre o que narrar, mesmo em relação às suas experiências. Movido por essa possibilidade de escolha, depois de tantas experiências limites, Levi se permite narrar a esperança de um tempo por vir, evidentemente por que "vale a pena contá-lo agora" (Ibidem).

A memória individual e coletiva é o fundamento do testemunho, e também deve ser o fundamento do teor ficcional nele presente. Em outras palavras, mesmo quando se vale do teor ficcional a narrativa deve produzir verossimilhança com a matéria narrada 
no testemunho, pois, o teor ficcional não pode ser o veículo para inconsistências que possam por ventura comprometer o critério da evidência necessário ao testemunho, do contrário a memória poderá cobrar a fragilização da evidência. É por isso que muitas vezes diante do testemunho não nos percebemos da ficcionalização da memória. Cito mais um episódio muito representativo desse aspecto, narrado por Levi:

\begin{abstract}
Nesse mundo, cada dia sacudido mais profundamente pelos estremecimentos do fim próximo, entre novos terrores e esperanças e intervalos de escravidão exacerbada, aconteceu-me encontrar Lourenço.

A história da minha ligação com Lourenço é, a um tempo, longa e breve, simples e enigmática; é a história de uma época e de uma situação já canceladas de qualquer realidade atual e, portanto, creio que não será compreendida a não ser, talvez, como se compreendem as lendas e os tempos mais remotos.

Em termos concretos, essa história restringe-se a bem pouco: um operário italiano me trouxe um pedaço de pão e os restos das suas refeições, cada dia, durante seis meses; deu-me de presente uma camiseta cheia de remendos; escreveu por mim um cartão-postal à Itália e conseguiu resposta. Por tudo isso não pediu nem aceitou compensação alguma, porque ele era simples e bom e não pensava que se deve fazer o bem a fim de receber algo em troca. (LEVI, 1988, p. 121)
\end{abstract}

O destaque deste episódio não está propriamente no que foi narrado em $E$ isto um homem? Trata-se do que Levi nos confessa em $O$ retorno de Lorenzo, narrativa que compõe os 71 contos de Primo Levi, material que se constitui de narrativas reconhecidas como ficcionais e publicadas como ficção. Sem dúvida, esses textos, são narrativas minimamente imersas pelo teor testemunhal, mesmo se declarando ficcionais. No caso da experiência com Lorenzo, Levi inicia o conto relacionando-o à escritura do seu testemunho e de como lhe foi difícil narrar histórias de pessoas vivas, principalmente quando os constituímos como personagens e não como pessoas, ou seja, Levi admite que, em É isto um homem?, muitas vezes estamos diante de episódios com válido teor ficcional. Cito Levi:

Lorenzo ainda vivia quando eu estava escrevendo $E$ isto um homem?, e a tarefa de transformar uma pessoa viva numa personagem bloqueia a mão de quem escreve. Isso ocorre porque uma tarefa assim, mesmo quando é conduzida com as melhores intenções e sobre uma pessoa querida e amada, beira a violência privada e nunca é indolor para quem é seu objeto. Cada um de nós elabora, conscientemente ou não, uma imagem de si, mas essa figura é fatalmente distinta daquela, ou melhor, daquelas, por sua vez diferentes entre si, que são construídas por quem se aproxima de nós, e ver-se retratado em um livro com traços que não coincidem com os que nos atribuímos é sempre traumático, como se o espelho de repente nos restituísse a imagem de

Revista Moara, n. 56, Vol. 2 jan-jul 2021 ISSN: 0104-0944 
um outro, quem sabe mais nobre que a nossa, mas não a nossa. (LEVI, 2005, p. 199; grifos meus)

Assim, me parece que há dificuldade em narrar quando temos a presença física do sobrevivente, de outra testemunha. A dificuldade se dá pela necessidade ficcionalização de muitas situações limites, que podem não ser compactuadas por outros testemunhos. Por isso, a passagem narrada por Levi é tão curta, mesmo que seja um episódio tão intenso e que o ajudou a sobreviver no campo. A retomada que Levi faz ao caso de Lorenzo, através da ficção assumida como ficção, me parece ter sido fundada na dificuldade que ele sentiu no momento da escritura de $E$ isto um homem?: a de ter condições de reunir os menores detalhes sobre o testemunho de um vivo, pois ele pode se voltar contra si, uma vez que a própria natureza fragmentária do testemunho muitas vezes impede a precisão em tudo o que é dito. Esse aspecto incide também sobre a forma como o tempo do discurso é manuseado no testemunho.

Haverá situações narradas, como neste excerto: “Quantos meses passaram desde a nossa entrada no Campo? Quantos, desde o dia em que recebi alta na enfermaria? E desde o dia da prova de Química? E desde a seleção de outubro?” (LEVI, 1988, p. 138), em que certamente a dificuldade em determinar o tempo é causada pelo trauma e o depauperamento do corpo e da mente, portanto, há momentos em que a dificuldade em estabelecer cronologias racionais não é uma estratégia narrativa constituída de caso pensado, mostra-se como uma fragilidade da testemunha por razões etiológicas.

Mas haverá momentos em que o tempo é percebido no testemunho de maneira muito fluida, ora com todos os detalhes, ora cheio de oclusões, por isso, também encontramos no texto de Levi a imprecisão do tempo, com fluxos temporais diretamente ligados à matéria narrada, mas que podem ser apresentados revestidos por estratégias do teor ficcional, com possibilidade de haver manuseios de prolepses, analepses, flashforward, flashback e até mesmo a autoconsciência narrativa sobre o tempo. São situações em que a imprecisão temporal alcança outro patamar, agora, sim, filtrado pelo teor ficcional, com o intuito de mostrar como o tempo pode ser efêmero e incontornável, em especial, na narração da experiência catastrófica:

Com todas as nossas forças, lutamos para que o inverno não chegasse. Nos agarramos a cada hora tépida; a cada crepúsculo, procuramos reter o sol ainda um pouco no céu, mas tudo foi inútil. Ontem o sol se pôs irrevogavelmente 
num emaranhado de névoa suja, de chaminés, de cabos, e hoje é inverno. (LEVI, 1988, p. 125)

A percepção poética do tempo se percebe claramente, na medida em que o narrador procura deter não só o tempo, mas também o sol, o calor, elementos que sustentam os códigos da existência movida pela dimensão cíclica das estações do ano, na qual o verão representa a possibilidade de estender o movimento, a vida, enquanto o inverno indica o afluxo crescente da paralisia e da morte. Por sinal, entre os ambientes narrados pelos sobreviventes em testemunhos da Shoah, nada é mais devastador do que o inverno, daí a necessidade de fazer imperar a manutenção de alguma forma de calor e fugir dos ditames do frio, como podemos ver a seguir em uma passagem do testemunho de Levi que apresenta um jogo recorrente no testemunho: a enunciação sai da voz narrativa e passa a voz imperativa e esse movimento se faz acompanhar também da progressão da voz testis para a voz superstes:

Chega. Acabou-se. É o último ato: começou o inverno e, junto com ele, a nossa última batalha. Já não há como duvidar: será a última. Qualquer que seja o instante do dia em que a gente dê ouvidos à voz de seu corpo, interrogue seus membros, a resposta é uma só: não aguentaremos. (LEVI, 1988, p. 139)

Não há como negar que a escrita de Levi é uma escritura da sobrevivência, que narra e testemunha ao mesmo tempo, reveste o tecido nas diversas estratégias, que não são exclusivas da narrativa literária, mas estão na narrativa oral também, pois, independente da modalidade, o testemunho prescinde de formas de dar sentido a memórias nebulosas, por isso, é em muitos casos poético, não como uma forma unívoca, mas como formulações plurívocas. Desse modo, ora trago o acontecimento sob minha perspectiva individual, sou uma testemunha superstes; ora sou a testemunha ocular, que dá voz a quem sucumbiu ou a quem não consegue dar seu testemunho e por isso sou testis; outras vezes, sou um escutador, e ponho-me a testemunhar aquilo que me contaram e que para mim, enquanto testemunha arbiter, considero fundamental que aquilo que testemunho seja repassado a outros, mesmo quando as pessoas que viveram a experiência alvo do testemunho ainda estão vivas. O testemunho é uma fresta, é uma fissura, que nos remete à necessidade, ora de evocar um teor testemunhal, ora um teor ficcional e, independente de um e do outro, um teor de verdade.

Revista Moara, n. 56, Vol. 2 jan-jul 2021 ISSN: 0104-0944 


\section{REFERÊNCIAS}

ANDRADE, Mariana. A tecitura filosófica de Walter Benjamin e os entrelaçamentos entre beleza e verdade. Cadernos Benjaminianos, v. 21; Belo Horizonte, p. 137-160, 2019. Disponível em https://www.gewebe.com.br/pdf/cad21/texto 08.pdf . Acesso em 06 fev 2021.

BARTHES, Roland. O efeito do Real. In. Literatura e Semiologia: pesquisas semiológicas. Petrópolis: Vozes, 1972.

BENJAMIN, Walter. Ensaios reunidos: escritos sobre Goethe; tradução de Mônica Krausz Bornebusch, Irene Aron e Sidney Camargo; supervisão e notas de Marcus Vinicius Mazzati. São Paulo: Duas Cidades; Ed. 34, 2009.

BENJAMIN, Walter. Magia, técnica, arte e política: ensaios sobre literatura e história da cultura (obras escolhidas, v.1). Tradução: Paulo Rouanet. $7^{a}$ ed. São Paulo: Brasiliense, 1994.

CAMINHA, Pero Vaz, A carta de Pero Vaz de Caminha. Brasília: MEC,1500. Disponível: http://objdigital.bn.br/Acervo_Digital/livros_eletronicos/carta.pdf. Acesso: 15 jan 2020.

FLUSSER, Vilém. Da ficção. In. O Diário de Ribeirão Preto, São Paulo, 26/08/1966. Disponível em: www.oocities.org/br/vilemflusser_bodenlos/textos/DAFICCAO.pdf. Acesso em fev 2021.

GALLE, Helmut P. E. O testemunho: um novo paradigma da ficção. In: GALLE, Helmut P. E., PEREZ, Juliana P., PEREIRA, Valéria S. (organizadores). Ficcionalidade: uma prática cultural e seus contextos. São Paulo: FFLCH/USP: FAPESP, 2018

HANSEN, João Adolfo. O "imortal" e a verossimilhança. Teresa revista literatura Brasileira. $\quad \mathrm{N}^{\mathrm{o}}$ 6-7; São Paulo, p. 56-78, 2006. Disponível em: https://www.revistas.usp.br/teresa/article/view/116608/114196. Acesso em 05 fev 2021.

LEVI, Primo. É isto um homem? Tradução: Luigi del Re. Rio de Janeiro: Rocco, 1988.

LEVI, Primo. 71 contos de Primo Levi. Tradução: Mário Santana Dias. São Paulo: Schwarcz, 2005.

MUNDURUKU, Daniel. O karaíba: uma história do pré-Brasil. Ilustração; Maurício Negro. Barueri-SP: Manole, 2010.

PESSOA, Fernando. Cancioneiro. Ciberfil Literatura Digital, 2003. Disponível em: www.dominiopublico.gov.br/download/texto/ph000003.pdf. Acesso em 27 fev 2020. 
RANCIÈRE, Jacques. O efeito de realidade e a política de ficção. Tradução Carolina Santos. Novos Estudos - CEBRAP. No 86, São Paulo: Mar 2010. P. 75-90. Disponível em: www.scielo.br/pdf/nec/n86/n86a04.pdf. Acesso em 01 maio 2020.

SAER, Juan José. O conceito de ficção. Tradução: Luís Eduardo Wexell Machado. Revista FronteiraZ, São Paulo: PUC-SP, n. 8, julho de 2012, p. 1-6. Disponível em: www.pucsp.br/revistafronteiraz/download/pdf/TraducaoSaer-versaofinal.pdf. Acesso em 17 maio 2020

SARMENTO-PANTOJA, Augusto. Performance e testemunho no cinema pós-64. Tese de doutorado. Instituto de Estudos da Linguagem, Universidade de Campinas. Campinas, 2016.

SARMENTO-PANTOJA, Augusto. O testemunho em três vozes: testis, superstes e arbiter. Revista Literatura e Autoritarismo. Santa Maria: PPGL/UFSM, n. 32, jan.jun. 2019, p. 5-18. Disponível em: https://periodicos.ufsm.br/LA/article/view/35461/20006. Acesso em 15 jan 2020.

SELIGMANN-SILVA, Márcio. História, Memória e Literatura: o testemunho na era das catástrofes. Campinas: Editora da UNICAMP, 2003.

SELIGMANN-SILVA, Márcio. Narrar o trauma - a questão de testemunho de catástrofes históricas. PSIC. CLIN., Rio de Janeiro, vol.20, N.1, p. 65-82, 2008. Disponível em: $\underline{w w w . s c i e l o . b r / p d f / p c / v 20 n 1 / 05}$. Acesso em 20 jan 2020

PLATÃO. A República. Tradução de Carlos Alberto Nunes. $3^{\text {a }}$ ed. Belém: EDUFPA, 2000.

Revista Moara, n. 56, Vol. 2 jan-jul 2021 ISSN: 0104-0944 